\title{
The Effect of Leadership Effectiveness and Interpersonal Communication on Teacher Job Satisfaction
}

\author{
Listi Jahro \\ SMA Negeri 5 Prabumulih \\ e-mail: listijahro@gmail.com \\ Edi Harapan \\ Universitas PGRI Palembang \\ e-mail: ehara205@gmail.com \\ Tahrun \\ Universitas PGRI Palembang \\ e-mail: tahrun@univpgri-palembang.ac.id \\ Article History: Received on 20 November 2021, Revised on 25 December 2021 \\ Published on 16 January 2022
}

\begin{abstract}
The purpose of this ex post facto correlational study is to investigate the impact of leadership effectiveness and interpersonal communication on teacher job satisfaction at SMA Sub Rayon III Prabumulih City. A questionnaire was utilized as the study tool. Inferential statistics, such as the basic linear correlation test, multiple linear regression, t-test, and F-test, were used to assess the data. The findings revealed a substantial relationship between leadership effectiveness and interpersonal communication and teacher job satisfaction at SMA Sub Rayon III Prabumulih. This research assists the principal in establishing effective communication in the school environment in order to achieve teacher job satisfaction.
\end{abstract}

Keywords: Leadership, Communication, Teacher Satisfaction

\section{A. Introduction}

A school is an institution that is utilized for educators' teaching and learning activities, as well as a venue for them to deliver and receive lessons in their respective professions. Schools are locations where children are educated with the goal of instilling information in them so that they can become valuable citizens of the nation and state. Schools play an essential part in the life of the nation, giving general information, fundamental skills, and preparing students for employment (Mahendrartha et al, 2020).

According to Government Regulation Number 32 of 2013, eight requirements must be followed in the implementation of education. Graduate competency requirements, content standards, process standards, standards for educators and education employees, facilities and infrastructure standards, management standards, funding standards, and educational assessment standards are among the eight standards. The standards of educators and education staff are competency criteria that are directly tied to the quality of education. Thus, in order to reach a high level of education quality, instructors and educational employees must be of high caliber. 
Volume 2 (3) 2021

E-ISSN: 2723-6919 P-ISSN: 2746-0827

Teachers, being one of the sources in schools, must have standard skills in order to carry out their responsibilities. According to Article 10 paragraph (1) of Law Number 14 of 2005 Concerning Teachers and Lecturers, teacher competences as referred to in Article 8 comprise pedagogic competence, personality competence, social competence, and professional competence achieved via professional education.

Professional instructors may be identified by their performance, which can result in optimum job satisfaction. Whether or whether the teacher's performance can be noticed in the work process or work outputs that will have an influence on educational progress. Education performance is one sign of a school principal's leadership success.

The presence of characteristics of creativity and productivity that are manifested via work outcomes indicates the high and low quality of human resources as development employees. This issue will be tied to the presence of instructors in the learning process, since teachers and educators carry out the duty. The teacher gives information, attitudes and beliefs, and abilities as a teacher. Meanwhile, instructors, as educators, must prepare their pupils to become mature human beings. Teachers have a duty and a high moral obligation for their pupils' success.

Job satisfaction is one of the characteristics that encourages instructors to work as hard as they can. Teacher job satisfaction is a type of teacher emotion and expression that occurs when a teacher is able or unable to achieve the requirements of the work process. Arises as a result of the process of changing his emotions and ideas into attitudes or values toward anything he does and receives.

Teachers are more likely to work enthusiastically if they are satisfied with their jobs, and job happiness is a crucial driver of morale, discipline, and teacher work performance in supporting the achievement of school goals. High teacher job happiness will make instructors more loyal, inspired to work, work with a sense of serenity, and, more crucially, high job satisfaction can enable high productivity. In contrast, if the teacher is dissatisfied with his or her tasks, it will result in poor work quality, as evidenced by absenteeism, laziness at work, the frequency of teacher complaints, poor job performance, poor teaching quality, teacher indiscipline, and other negative indicators. As a result, both within the scope of the school and for the world of education in general, this might impede the attainment of educational goals. The above can arise as a result of the principal's leadership.

Principals must be able to lead successfully and play a significant part in driving school life forward by establishing influence on teachers so that they carry out their responsibilities totally and joyfully. One of the principal's leadership responsibilities is to empower teachers and delegate extensive authority to enhance teacher teaching performance so that the learning process produces optimal results (Kartini et al, 2020). Aside from the teaching component, the feature of the principal's leadership abilities will influence the success of education in the current state of our education. Principals must meet stringent leadership quality standards. School success can only be attained via the guidance of a knowledgeable principal.

The writers highlight the challenges that exist in SMA Sub Rayon III Prabumulih City based on the problem's background. According to the author's findings, there are schools that have been operating for a long time with principals who have been there for more than 5 years, but the advancement of these schools is not noteworthy, and teacher performance is likewise static, and in some cases deteriorating. 
Volume 2 (3) 2021

E-ISSN: 2723-6919 P-ISSN: 2746-0827

There are other schools that have just recently been formed but have been able to match, if not outperform, the quality and quantity of previously established schools. The facilities, student learning outcomes (both academic and non-academic), and instructor performance all demonstrate the school's excellence. Teaching and learning settings are less successful at one school, as seen by the teacher's frequent tardiness to school, causing the class to be taught to fall outside of the planned hours. School hours are seldom kept on schedule, and students frequently leave before the end of the day. Principals have less ability to alter less favourable situations into more conducive conditions. This has an effect on teacher performance and student achievement.

The principal lacks a high fighting spirit to change in order to better the situation, as well as the adoption of a leadership style that is not yet adequate and adaptable in line with the conditions and demands of the school. Teachers are less likely to perform effectively in school scenarios and conditions, as well as in social and professional contexts that are not supportive. As a result, the teacher's performance suffers (Diana et al, 2020).

There are principals who are less transformational in terms of monitoring and assessing teacher performance and program implementation, less aspirational, and lacking in terms of creating a participatory culture for all school members. As a leader, he does not reject recommendations or criticism from subordinates, but the teacher's ambitions and proposals are not accepted and are even not adopted, even if the suggestions or critiques are for the betterment or improvement of school quality (Suratman et al, 2020).

If there is a disagreement of opinion or a need to find a solution, the principal is less inclined to debate. Principals who are less transformational are incapable of motivating and energizing teachers and education professionals in schools. In reality, the example set by the principal's behavior may become a potent weapon for influencing and moving teachers and education workers to support every school program. Meanwhile, external problems include teachers', education staff's, school committees', and the community's unwillingness to fully support school initiatives, as well as inadequate government funding (Jaliah et al, 2020).

Teachers' involvement and quality are still low, so teachers have been unable to carry out the tasks delegated by the principal, forcing the principal to carry out his duties independently, and empowerment and broad authority granting to teachers to improve their teaching performance is still lacking. Due to a lack of principle guidance, diverse habits, desire, and talents of instructors make it difficult for school administrators to adopt new programs and unite the vision and mission.

The slow improvement in the quality of education in schools is due to teachers' lack of commitment to learning, so there are still many teachers who work just because they are afraid of the principal, and when the principal is not in school or has other interests, they do not work properly, resulting in low teacher performance as a result of leadership and managerial processes in schools that are still less effective and efficient.

Qualified principals are those who possess fundamental leadership abilities, great personal credentials, and professional knowledge and skills. The principal's capacity to lead may be observed in the school's rising progress, both academic and non-academic. Academically, this entails increasing the performance of school leaders, instructors, and students. Meanwhile, 
from a non-academic standpoint, the number of facilities and infrastructure held by schools has grown, as has the public's interest in enrolling their children in school.

This is according to the author's findings from an interview with the principal of SMA Negeri 6 Prabumulih on March 3, 2020. "The success of the principal in managing a school cannot be isolated from the principal's competency," he added. "A school administrator must master five characteristics," he says: "personality, management, entrepreneurial, supervisory, and social competence".

Having these qualities can help school administrators develop and lead their schools more effectively. This has been demonstrated through SMA Negeri 6 Prabumulih's 13-year leadership term, during which time a great deal of development has been made. During his tenure, he oversaw a $70 \%$ rise in buildings and infrastructure, as well as an $85 \%$ improvement in teacher performance. Increasing the number of SMAN6 graduates who attend public colleges.

The number of tournaments won by students of SMAN 6 Prabumulih shows a growth in nonacademic accomplishments from year to year. Furthermore, on March 4, 2020, the author did another interview with the head of SMA Negeri 5 Prabumulih, Mr. Dr. Suharman, M.Pd.I, who stated that the principal's success in leading is based on the principal's vision and purpose. However, this Vision and Mission cannot be completely fulfilled as planned due to a variety of factors. This school, SMA Negeri 5 Prabumulih, was founded in 2015. SMA Negeri 5 Prabumulih has also made development, albeit not as quickly as SMAN 6 Prabumulih.

At this school, kids get character education in the areas of religion, discipline, and environmental stewardship. It is possible to make youngsters aware of religion by providing religious instruction, because religion can strengthen juvenile delinquency. SMA Negeri 5 enforces strict discipline for students, teachers, and other educational workers. By acting like students, discipline may promote a feeling of responsibility. With a passion for the environment, kids may learn to coexist with nature and develop an ethical attitude toward plants and animals. Student accomplishment may be improved via the development of character in pupils.

Because not all principals are capable of carrying out leadership duties effectively, the authors are keen to investigate the effectiveness of leadership and interpersonal communication between principals in increasing job satisfaction in schools and transforming them into advanced and quality institutions. The author expects that the findings of this study will be useful as reflective material for school administrators and students, as well as other parties interested in enhancing the quality of education in SMA Sub Rayon III Prabumulih in the future.

Communication is one of the activities that cannot be isolated from human daily existence. Because humans are always in contact with one another. Interpersonal communication refers to communication that takes place between two people. Communication can take place in either a professional or casual setting. Interpersonal communication takes happen in a formal setting, such as a school or a school organization. This communication serves to raise motivation, allowing instructor performance to improve as well. Interpersonal communication refers to communication that takes place between two people. Communication can take place in either 
a professional or casual setting. Interpersonal communication takes happen in a formal setting, such as a school or a school organization.

The aforementioned issues may be used to assess a leader's performance, which will have an impact on teacher job satisfaction. A teacher must use excellent communication skills to foster good collaboration with coworkers, leaders, students, and the surrounding community in order to promote job satisfaction. The capacity of the teacher to communicate, particularly interpersonal communication, will demonstrate a pleasant, trustworthy, and open attitude, which can boost teacher work satisfaction.

In a school organization, it is important to carry out effective communication. Suwatno and Priansa (2011) state that one of the most important types of interpersonal communication within the scope of school organizations is: communication between superiors and subordinates. This communication has a function to increase motivation so that teacher performance can also improve.

\section{B. Methods}

This study was carried out at high schools in Prabumulih's Sub-Rayon III, including SMA Negeri 5, SMA Negeri 6, SMA PGRI, and SMA Taman Siswa. The research population consists of 154 instructors from all SMA Sub Rayon III Prabumulih City. The purpose of this study was to determine the impact of leadership effectiveness and interpersonal communication on teacher job satisfaction at SMA Sub Rayon III Prabumulih City. The expost facto approach, which is used in correlational research, is used in this study. Expost facto study refers to events that have already occurred. Expost facto research, as defined by Sugiyono $(2011 ; 2015)$, is research conducted after an occurrence has occurred. This study employs a questionnaire-based data gathering approach. In this study, the data were analyzed using inferential statistics such as the simple linear correlation test, multiple linear regression, t-test, and f-test.

\section{Results and Discussion}

\section{Leadership Effectiveness and Job Satisfaction of High School Teachers Sub Rayon III Prabumulih City}

The results of testing the hypothesis of the effect of Leadership Effectiveness on Teacher Job Satisfaction in SMA Sub Rayon III Prabumulih City show that there is a positive influence between Leadership Effectiveness on Teacher Job Satisfaction in SMA Sub Rayon III Prabumulih City with a significance value of 0.00 , which is less than 0.05 . By looking at this result, we may conclude that Ho is acceptable and that this regression model is satisfactory. So, in SMA Sub Rayon III Prabumulih City, there is a considerable relationship between leadership effectiveness and teacher work satisfaction.

The findings of this study are supported by the findings of a previous study conducted by Khusnuddin (2017) entitled The Effect of Madrasah Principal Leadership Effectiveness and Physical Work Environment on Teacher Performance at MA Darul Huda Mayak Ponorogo Academic Year 2015/2016, which found that there is a positive and significant influence between leadership effectiveness and teacher job satisfaction, as well as a positive and significant influence between interpe sonal communication on teacher job satisfaction. Furthermore, Rasmuji et al. (2017) conducted research with the title The Effect of Effectiveness 
Volume 2 (3) 2021

E-ISSN: 2723-6919 P-ISSN: 2746-0827

of Leadership and Work Environment on Employee Performance with the Mediation Role of Job Satisfaction (Study on PD. BPR BKK Batang), which found that the effectiveness of leadership and interpersonal communication has a significant influence on employee job satisfaction.

To attain excellence and quality education, all components must be present, including students, resources, media, facilities and infrastructure, curriculum, and funding. However, none of these components will be optimal in terms of improving the quality, teaching, and learning process unless they are supported by the presence of professional teachers and the level of comfort in this case how much teacher job satisfaction and leadership effectiveness is owned by the Principal and Communication between fellow Teachers, and Communication between Teachers and the Principal (Darmiati et al, 2020).

Each indicator in this study includes competence in having a strong personal trait in the occasional category, understanding the condition of teachers, employees, and students in the occasional category, having a vision and understanding the school's mission in the occasional category, the ability to make decisions in the occasional category, and the ability to communicate in the occasional category. As a result, it is possible to say that leadership effectiveness in SMA Sub Rayon III Prabumulih is on the rare side.

\section{Interpersonal Communication and Teacher Job Satisfaction at SMA Sub Rayon III Prabumulih}

According to the findings of the hypothesis testing the Effect of Interpersonal Communication on Teacher Job Satisfaction in SMA Sub Rayon III Prabumulih City, there is a positive influence between Interpersonal Communication and Teacher Job Satisfaction in SMA Sub Rayon III Prabumulih City with a significance value of 0.000 , which is less than 0.05. By looking at this result, we may conclude that Ho is acceptable and that this regression model is satisfactory. So, at SMA Sub Rayon III Prabumulih City, there is a considerable connection between Interpersonal Communication and Teacher Job Satisfaction.

The findings of this study are supported by the findings of Loina's earlier research (2012). Improving Job Satisfaction and the Effectiveness of Superior-Subordinate Interpersonal Communication at PT. X. Depok demonstrates that the descriptive findings suggest that the Interpersonal Communication variable has a substantial influence on Employee Job Satisfaction.

Communication is the exchange of information between two or more individuals. Communication is an important activity in school organizations since it is required for the efficacy of leadership, planning, control, coordination, training, dispute resolution, and other organizational activities. Interpersonal communication is typically characterized as main communication and refers to people who rely on one another and share a common background. This might be a dialogue or an individual communicating with a large number of individuals in society. It enables us to comprehend how and why individuals behave and communicate in various ways in order to build and navigate social realities.

In particular, each sign in Interpersonal Communication has four indicators: Empathy Competence in the Rare category, Support in the Rare category, Positive Attitude in the Rare 
category, and Equality in the Rare category. As a result, interpersonal communication in SMA Sub Rayon III Prabumulih falls into the unusual group.

\section{Effectiveness of Leadership, Interpersonal Communication and Teacher Job Satisfaction at SMA Sub Rayon III Prabumulih}

A significant value of 0.006 is reached based on the findings of the computation of the hypothesis of the influence of Leadership Effectiveness and Interpersonal Communication on Teacher Job Satisfaction at SMA Sub Rayon III Prabumulih City, which is less than 0.05. By looking at this result, we may conclude that Ho is acceptable and that this regression model is satisfactory. As a result, in SMA Sub Rayon III Prabumulih City, there is a considerable relationship between leadership effectiveness and interpersonal communication. In this study, the markers of Teacher Job Satisfaction include the work itself in the Rare category, Salary or remuneration in the Rare category, Promotion Opportunities in the Rare category, Supervision in the Rare category, and Colleagues in the Rare category. Interpersonal Communication on Teacher Job Satisfaction is considered Rare.

\section{Conclusion}

Leadership effectiveness has a strong influence on teacher work satisfaction in SMA Sub Rayon III Prabumulih City. Interpersonal communication has a strong impact on teacher work satisfaction at SMA Sub Rayon III Prabumulih City. The efficacy of leadership and interpersonal communication have a substantial impact on teacher work satisfaction at SMA Sub Rayon III Prabumulih City.

\section{E. Acknowledgement}

We thank to the principal of SMA Negeri 5 Prabumulih, Rector Universitas PGRI Palembang, and friends of graduate program educational management Universitas PGRI Palembang who have supported us to do this project.

\section{References}

Darmiati, D., Kristiawan, M., \& Rohana, R. (2020). The Influence of School Leadership and Work Motivation toward Teacher's Discipline. Journal of Social Work and Science Education, 1(1), 32-44. https://doi.org/10.52690/jswse.v1i1.8

Diana, R., Ahmad, S., \& Wahidy, A. (2020). Pengaruh Motivasi Kerja dan Komunikasi Interpersonal Terhadap Kinerja Guru [The Influence of Work Motivation and Interpersonal Communication on Teacher Performance]. Jurnal Pendidikan Tambusai, 4(3), 1828-1835. https://doi.org/10.31004/jptam.v4i3.653

Government Regulation Number 32 of 2013

Jaliah., Fitria, H., \& Martha, A. (2020). Pengaruh Kepemimpinan Kepala Sekolah dan Manajemen Kepala Sekolah terhadap Kinerja Guru [The Influence of Principal Leadership and Principal Management on Teacher Performance]. Journal of Education Research, 2, 146-153 
Volume 2 (3) 2021

E-ISSN: 2723-6919 P-ISSN: 2746-0827

Kartini., Ahmad, S., \& Eddy, S. (2020). Pengaruh Gaya Kepemimpinan Kepala Sekolah Dan Komunikasi Interpersonal Terhadap Kinerja Guru [The Influence of Principal's Leadership Style And Interpersonal Communication On Teacher Performance]. Journal of Education Research, 3, 290-294

Khusnuddin, M. (2016). Pengaruh Efektivitas Kepemimpinan Kepala Madrasah dan Lingkungan Kerja Fisik Terhadap Kinerja Guru di MA Darul Huda mayak Ponorogo Tahun Akademik 2015/2016 [The Effect of Effectiveness of Madrasah Principal Leadership and Physical Work Environment on Teacher Performance at MA Darul Huda Mayak Ponorogo Academic Year 2015/2016]. Masters thesis, IAIN Ponorogo.

Law Number 14 of 2005 Concerning Teachers and Lecturers

Loina, E., Mokoginta, U. A., Graito, B. I., Soemitro, L. J., \& Sjabadhyni, B. (2012). Meningkatkan kepuasan kerja dan efektivitas komunikasi interpersonal atasan-bawahan melalui program pelatihan komunikasi interpersonal pada supervisor di PT. X [Improving job satisfaction and superior-subordinate interpersonal communication effectivity through interpersonal communication training program for supervisor in PT. $\mathrm{X}]$

Mahendrartha, A., Tobari, T., \& Tabula, R. V. (2020). Adiwiyata-Based School Management in Indonesia. Journal of Social Work and Science Education, 1(1), 1-7. https://doi.org/10.52690/jswse.v1i1.4

Rasmuji, R., \& Putranti, H. R. D. (2017). Pengaruh Efektivitas Kepemimpinan Dan Lingkungan Kerja Terhadap Kinerja Karyawan Dengan Peran Mediasi Kepuasan Kerja (Studi pada PD. BPR BKK Batang) [The Effect of Leadership Effectiveness and Work Environment on Employee Performance with the Mediation Role of Job Satisfaction (Study on PD. BPR BKK Batang)]. Media Ekonomi dan Manajemen, 32(2).

Sugiyono (2011). Statistika Untuk Penelitian [Statistics For Research]. Bandung: Alfabeta.

Sugiyono. (2013). Metode Penelitian Kuantitatif, Kualitatif, dan $R \& D$ [Quantitative, Qualitative, and $R \& D$ Research Methods]. Bandung: Alfabeta.

Suratman, S., Arafat, Y., \& Eddy, S. (2020). The Influence of Principal's Leadership and Teacher's Competence toward Teacher's Performance in Indonesia. Journal of Social Work and Science Education, 1(2), 96-104. https://doi.org/10.52690/jswse.v1i2.32

Suwatno., \& Priansa, D. (2011). Manajemen SDM dalam Organisasi Publik dan Bisnis [HR Management in Public and Business Organizations]. Bandung: Alfabeta.

Umami., Siti. Lian, B., \& Missriani. (2021). Pengaruh Kepemimpinan dan Motivasi Kerja Guru Terhadap Disiplin Kerja [The Influence of Teacher Leadership and Work Motivation on Work Discipline]. JMKSP (Jurnal Manajemen, Kepemimpinan, dan Supervisi Pendidikan), 6(1). 